УДК 94 (477.72) «1945/1955»

DOI: https://doi.org/10.33782/eminak2019.4(28).344

\title{
ВІДНОВЛЕННЯ ТА ДІЯЛЬНІСТЬ КЛУБІВ НА МИКОЛАЇВЩИНІ У ПОВОЄННИЙ ПЕРІОД (1945-1955 РР.)
}

\author{
Ганна Маринченко1, Віра Ревенко 2 \\ Миколаївський національний ун-т імені В.О. Сухомлинського (Миколаїв, Україна) \\ ${ }^{1}$ e-mail: anya.marinchenko@gmail.com; ORCID: https://orcid.org/0000-0003-3208-0546 \\ 2e-mail: verarevenko84@gmail.com; ORCID: https://orcid.org/0000-0002-1043-6890
}

Розкрито особливості відновлення та діяльності культурно-просвітницьких установ Миколаӥвської області на селі, їх культурну, просвітницьку та політико-масову роботу з селянством у повоєнний період. Діяльність всіх культурно-просвітницьких установ у досліджуваний період жорстко регламентувалася вищим партійним керівництвом. Суворо перевірявся репертуар і виконавці. Робота культпрацівників стримувалася партійною верхівкою, а розвиток культури гальмувався.

Ключові слова: будинок культури, культурно-просвітницька робота, художня самодіяльність, дозвілля, селянство, Миколаївщина

Культурно-масова робота $є$ складовим елементом життя кожного народу, що сприяє його самоідентифікації та збереженню історичних і народних традицій. У радянський період на заклади культури покладався великий обсяг роботи і щодо донесення інформації до населення: політичної, історичної, культурної. Найбільше роботи, звичайно, припадало саме на заклади культури у сільській місцевості - будинки культури та клуби. Соціальний розвиток українського села, а особливо такий його елемент як відбудова культурно-просвітницьких закладів, є доволі актуальним у наш час. Адже навіть на сучасному етапі розвитку української держави, клуби у сільській місцевості продовжують подекуди залишатися єдиним осередком культурного та громадського життя села.

Однією з помітних тенденцій сучасної історичної науки є звернення уваги дослідників до історії повсякденного життя суспільства. У колі наукових пошуків повсякденного життя на селі важливе місце посідають його гуманітарні аспекти, зокрема діяльність клубів у повоєнний період. Дослідження відновлення та діяльності сільських клубів повоєнного періоду обумовлено необхідністю врахування практичного досвіду роботи минулого в організації культурної роботи серед сільського населення в сучасних умовах українського села.

Проблема діяльності сільських клубів розглядалася істориками переважно у загальнодержавному масштабі. В цьому напрямку варто виділити роботи В. Мічуди ${ }^{1}$ I. Романюка², I. Рибака ${ }^{3}$ С. Румянцева ${ }^{4}$, O. Шамрай 5 та ін.

\footnotetext{
${ }_{1}^{1}$ Мічуда В. Культурне будівництво на селі в перші повоєнні роки (1945-1950рр.) // Україна XX ст.: культура, ідеологія, політика. Вип. 7. Київ, 2003. С. 403-408.

2 Романюк І.М. Українське село в 50-ті - першій половині 60-х рр. XX ст. Вінниця: Книга-Вега, 2005. $256 \mathrm{c.}$

3 Рибак І.В. Соціально-побутова інфраструктура українського села 1921-1991 рр. Кам'янецьПодільський: Абетка, 2000. 303 с.

4 Румянцев С. Самодеятельное художественное творчество в СССР: очерки истории 1950-1990 гг. Москва: РОССПЭН, 1999. 535 с.
} 
Саме тому, метою даної роботи є дослідження діяльності культурно-просвітницьких установ Миколаївської області, їх культурна, просвітницька та політикомасова робота з селянством у повоєнний період.

Першочерговою справою у повоєнний період стало відновлення роботи закладів освіти, науки і культури 6 . Основним осередком громадсько-культурного життя та спілкування односельців стали клуби, які мали помітний вплив на формування громадської думки, настроїв і загальної культури сільського населення.

Так, для координації роботи клубних установ при Раді Міністрів було створено комітети у справах культурно-просвітницьких установ зі значними повноваженнями в справах культурно-виховної роботи. В обласних і міських Радах самостійні відділи культурно-просвітницьких установ, при районних Радах - окремі інспектори у справах культурно-просвітницьких установ 7 . Інструктивно-методичний лист Центрального науково-методичного кабінету культурно-освітньої роботи, який направлено у 1946 р. на місця, визначав першочергові завдання: «рішення партії вимагають від працівників ідеологічного фронту, в тому числі і від культурно-освітніх працівників, до кінця викрити і засудити прояви аполітичності, безідейності в роботі i, paзом з тим, посилити виховання трудящих у комуністичному дусі» ${ }^{8}$.

Сформульовані у партійних документах настанови складали основу методичних рекомендацій культурно-освітніх відомств з питань організації клубної роботи на селі9. У червні 1946 р. Комітет у справах культурно-просвітницьких установ при РМ СРСР затвердив «Положення про державний сільський клуб», яким мали керуватися у роботі місцеві організації. Керівництво здійснювалося завідуючим і радою клубу, що складалася з представників партійної та комсомольської організацій, сільської ради колгоспу або радгоспу.

На основі цього «Положення» розроблено проект будівлі сільського клубу, у складі якого передбачалися зала для глядачів зі сценою, фойє, бібліотека-читальня, кімната для гурткової роботи та відпочинку, спортивний майданчик, радіо, комплекти музичних інструментів і настільних ігор, спортивний інвентар 10.

Так, на вищому державному рівні планували та регламентували діяльність клубних установ. А ось на місцях картина дещо відрізнялася.

У кожному населеному пункті, визволеному від загарбників, саме силами місцевих жителів відбудовувалися та ремонтувалися будинки культури, клуби, а також кіномережа 11 . Культосвітні установи відбудовувалися методом народної будови, що було ефективно, однак і будь-яке будівництво вимагало значних капіталовкладень, про що так часто забувала радянська влада. Це призводило до невиконання плану відбудови та відсутності клубів у деяких населених пунктах ${ }^{12}$.

\footnotetext{
5 Шамрай О.Г. Художня самодіяльність та інші форми дозвілля у повоєнному українському селі // Вісник Черкаського університету. Серія «Історичні науки». 2008. № 133-134. С. 161-166.

${ }^{6}$ Носіков Ю.В. Відбудова закладів культури, освіти та охорони здоров'я в 1943-1945 pр. // Український історичний журнал. 1978. № 5. С. 69.

7 Державний архів Миколаївської області (ДАМО). Ф. П-7. Оп. 4. Спр. 326. Арк. 32.

8 Шамрай О.Г. Вказ. пр. С. 161.

9 Терещенко Т.В. Відбудова сільських культурно-освітніх установ у 1943-1950 pp. (на матеріалах Центральної України) // Історія України. Маловідомі імена, події, факти. Вип. 26. Київ, 2004. C. 353.

10 Ibid. C. 356

${ }^{11}$ Шамрай О.Г.Вказ. пр. С. 167.

12 ДАМО. Ф. П-7. Оп. 4. Спр. 208. Арк. 19.
} 
Значну допомогу надавали комсомольці та сільська молодь, які відбудували сотні клубів і будинків культури. Так, наприклад, комсомольці та сільська молодь колгоспу «Червоний труд» Ново-Бузького району Миколаївської області методом народної будови збудували колгоспний клуб. Під керівництвом партійних організацій, комсомольці виповнили взяті зобов'язання на честь XXX-річчя ЛКМСУ. На день ювілею комсомолу України відремонтували та побудували 120 сільських і 157 колгоспних клуби. 31 січня 1945 р. по 1 січня 1946 р. на Миколаївщині відбудовано 203 культурно-просвітницьких установи, з них: районних клубів і будинків культури - 4, сільських - 69, колгоспних клубів - 2413 .

Всього за два роки і два місяці, з дня звільнення Миколаївщини, відновили свою роботу у сільських районах: 19 будинків культури, 202 сільських клуба, 185 колгоспних клубів, 16 кінотеатрів ${ }^{14}$. Наведені цифри свідчать про недостатність розмаху відбудови культурно-просвітницьких установ у сільських районах, особливо у Варварівському, Володимирівському, Жовтневому, Широколанівському, Очаківському районах Миколаївської області. Наприклад, в Очаківському районі у 1946 р. при наявних 14 сільських радах, клуби було відбудовано тільки у 9 колгоспах. Потрібно зазначити, що Очаківські районні організації, незважаючи на те, що з моменту звільнення пройшло два роки, не мали повного обліку культурно-просвітницьких установ, що свідчило про незадовільний стан їхньої роботи.

По факту план відбудови клубів залишався незадовільним і в 1950-х роках. Мережа клубних установ у 1950 р., в порівнянні з 1949 р., зросла тільки на 0,3\%, тобто на один клуб. У порівнянні з 1940 р. мережа сільських клубів у 1950 р. не досягла довоєнного рівня та складала 97,9\%15.

Невиконання плану пояснювалося згортанням колгоспних клубів у зв'язку з укрупненням колгоспів. Після злиття, колгоспи перетворилися на бригади, а сільські клуби стали бригадними. Укрупнення колгоспів (до укрупнення на Миколаївщині нараховувалося 960 колгоспів, а залишилося 357) зменшилася кількість клубних установ на 250 одиниць.

У 1950 р. в області нараховувалось 29 колгоспів, де не було жодного бригадного чи колгоспного клубу. Клубних установ не мали 269 виробничих бригад ${ }^{16}$.

Значна кількість культурно-просвітницьких установ існувала тільки на папері. 3 10 сільських клубів Новоодеського району через відсутність приміщення не працювали: Новопетрівський, Артемівський і Суворівський клуби. Також вважався працюючим клуб у Сухоєланецькій сільській ради, але він не працював, оскільки приміщення зайняли під сільську раду, тоді як приміщення сільської ради віддали під квартиру ветеринару ${ }^{17}$.

Відсутність приміщень викликала значні незручності та впливала на проведення культурно-просвітницьких заходів. Доходило навіть до певних курйозів. Так, наприклад, у 1951 р. у с. Кандибине Новоодеського району Миколаївської області приїхала кінопересувка. Приміщень для перегляду кінофільму, окрім тваринницьких ферм, не було. Однак і вони були засипані зерном. Бригадир наказав вивести коней з конюшні та навести там лад для перегляду кінофільму. Під час демонстрація пішов

\footnotetext{
13 Ibid. Спр. 326. Арк. 125.

14 Ibid. Спр. 334. Арк. 1.

15 ДАМО. Ф. П-7. Оп. 8. Спр. 26. Арк. 71.

16 Ibid. Оп. 7. Спр. 449. Арк. 2.

17 Ibid. Оп. 4. Спр. 334. Арк. 1.
} 
дощ, коней завели у конюшню та поставили з однієї сторони, а глядачів - з іншої18.

На культурне будівництво виділялося досить незначні асигнування 19 . Всього на 1946 р. виділено 3332 тис. крб.20 У середньому на один Будинок культури припадало по 25-30 тис. крб., що, звичайно, не могло задовольнити потреби сільської культпросвіти.

Також варто зауважити, що відпущені кошти районами використовувалися незадовільно, фінансові органи своєчасно не виділяли гроші, більш того, траплялися випадки коли по три-чотири місяці не виплачували заробітну плату працівникам культурно-просвітницьких установ. У результаті того, що райкоми партії не брали безпосередньо під свій контроль відпущенні кошти, у 1945 р. їх використано лише $53 \%{ }^{21}$. Бували випадки, що кошти використовувалися не повністю через нестачу будівельних матеріалів, робочих рук, техніки 22.

У деяких селах і колгоспах мали місце факти використання культурнопросвітницьких установ не за призначенням: клуби засипали зерном, переробляли під сушарки, конюшні, пташники, гуртожитки й ін. ${ }^{23}$

Зовнішній вигляд клубів також був зовсім непривабливий: занедбані, брудні, без дахів, кути споруд відбиті, стіни та стелі потріскані, вікна закладені каменем так, що денне світло не проникало 24 . Навколо клубів були відсутні зелені насадження, під вікнами брудно, зсередини більшість клубів потребували капітального ремонту відсутня підлога, печі, стелі й стіни обвалювалися 25.

У 1951 р. в Миколаївській області приміщення сільських і колгоспних клубів у низці районів представляли собою споруду барачного типу або це були переобладнані сараї, без додаткових кімнат для клубного активу. У Березнегуватському районі приміщення Добринського сільського клубу не мало жодного вікна 26 . Не всі сільські клуби мали зали для глядачів, за малого об’єму мали недостатню кількість місць. Місця в залах для глядачів були обладнані тільки на 62\%, особливо погано у Баштанському, Братському, Варварівському, Новоодеському районах 27.

Матеріальна база культпросвітніх закладів була дуже слабка28. У клубах були відсутні стільці та лавки, електроенергія й опалювальні лампи, під час вечорів приміщення освітлювалося коптилками ${ }^{29}$. У більшості клубів не було жодного музичного інструменту, також відсутні такі ігри як шахи, доміно, шашки та спортивний інвентар. У клубах Миколаївської області у 1946 р. нараховувалося 35 піаніно, 13 патефонів, 40 духових оркестрів, 32 струнних інструменти, 19 баянів. Бутафорія - декорації, костюми, грим та інше приладдя для драмгуртків знаходилася у недостатній кількості 30 .

Мало уваги приділяли сільським клубам виконкоми сільських рад і сільські пар-

\footnotetext{
18 Ibid. Оп. 8. Спр. 295. Арк. 71.

19 Державний архів Херсонської області (ДАХО). Ф. Р-1989. Оп. 1. Спр. 98. Арк. 72.

20 Ibid. Ф. Р-1948. Оп. 1. Спр. 55. Арк. 40.

21 ДАМО. Ф. П-7. Оп. 8. Спр. 295. Арк. 72.

22 ДАХО. Ф. Р-1979. Оп. 3. Спр. 568. Арк. 32.

23 ДАХО. Ф. Р-1989. Оп. 1. Спр. 27. Арк. 4.

24 ДАМО. Ф. П-7. Оп. 4. Спр. 334. Арк. 73.

25 Ibid. Арк. 74.

26 Ibid. Оп. 6. Спр. 189. Арк. 72.

27 Ibid. Арк. 73.

28 Ibid. Оп. 4. Спр. 334. Арк. 76.

29 Ibid. Оп. 7. Спр. 334. Арк. 74.

30 Ibid. Арк. 76.
} 
тійні організації, внаслідок чого вони не забезпечувалися вчасно паливом, були непідготовлені до зими 31 . Підготовка культурно освітніх установ до роботи у зимовий період 1947-48 рр. у цілому по УРСР була визнана незадовільною у результаті більшість клубів зимою не працювали. Однак стверджувати, що культурнопросвітницькі установи нічого у цей період не робили, не $є$ правильним. Під час підготовки виборів до Верховної Ради СРСР наявні клуби проводили велику політмасову роботу 32 .

Одним із головних напрямків роботи сільських клубів у повоєнний період була організація художньої самодіяльності. На 1 січня 1946 р. у Миколаївській області працювало 1187 гуртків (політичні, оборонно-фізкультурні, агротехнічні й ін.). Кількість гуртків художньої самодіяльності за 1945 р. збільшилася на 302 одиниці33. Репертуар гуртків суворо регламентувався та контролювався, влаштовували спектаклі, концерти, тематичні вечори 34 .

Хорові та музичні гуртки, головним чином, виконували популярні народні пісні. Якість виконання була невисока. Працювали в більшості без нот, а на слух ${ }^{35}$. Траплялися випадки, коли гуртки художньої самодіяльності давали концерти абсолютно не підготовлені, що призводило до дезорганізації й уходу глядачів ${ }^{36}$. Склад керівників гуртків слабкий, їх підготовці не приділялося належної уваги ${ }^{37}$.

У 1952 р. перевірка показала значне зростання хорової та музичної культури, покращення репертуару гуртів художньої самодіяльності. Збільшилася кількість музичних гуртків. У багатьох районах області у сільських і колгоспних клубах створені духові оркестри, оркестри народних інструментів, а також збільшилась кількість колгоспних хорів і хорових ланок. У цьому відношенні варто відмітити Новоодеський, Широколанівський, Братський, Привільнянський, Жовтневий і Вознесенський райони Миколаївської області.

Одночасно, у деяких районах продовжували мати місце факти байдужого ставлення окремих районних керівників до розвитку художньої самодіяльності. Так, наприклад, виконком Арбузинського району навіть не прийняв рішення про підготовку та проведення огляду художньої самодіяльності. Байдужість до підготовки огляду хорових колективів проявили виконкоми Тилігуло-Березанської, Березнегуватської райради депутатів трудящих. Виконком Варварівської райради не допоміг гуртківцям транспортними засобами, вважаючи це не своїми зобов'язаннями ${ }^{38}$.

У 1954 р. гуртки художньої самодіяльності працювали нерегулярно. Плани роботи не виконувалися. Недолікам гурткової роботи була сезонність, коли з початком масових робіт у полі значна частина гуртків згортала роботу або зовсім припиняли їі.

Головне місце у діяльності сільських клубів займала лекційна робота. Вона проводилася штатними лекторами обласних і районних лекторських груп, сільськими вчителями. Тематика переважно стосувалася міжнародного становища, внутрішньої політики партії, окремих питань суспільно-політичного життя ${ }^{39}$. Колгоспники, у більшо-

\footnotetext{
31 Ibid. Ф. Р-992. Оп. 6. Спр. 450. Арк. 35.

32 ДАМО. Ф. П-7. Оп. 4. Спр. 334. Арк. 3.

33 Ibid. Спр. 210. Арк. 125.

34 Мічуда В.В. Вказ. пр. С. 38.

35 ДАМО. Ф. П-7. Оп. 4. Спр. 210. Арк. 17.

36 Ibid. Спр. 334. Арк. 3.

37 Ibid. Спр. 210. Арк. 17.

38 Ibid. Ф. Р-992. Оп. 6. Спр. 450. Арк. 144-145.

39 Положення про сільській лекторій // Культурно-освітня робота. Київ: Рад. Україна. 1949. С. $42-43$.
} 
сті випадків, відвідували лекції неохоче, слухали неуважно, розмовляли, спали ${ }^{40}$.

В обласному лекційному бюро на 31 грудня 1947 р. працювало 2 штатних і 78 нештатних лекторій і 960 лекторів. Враховуючи, що у Миколаївській області нараховувалося 943 населених пункти, наявність такої кількості лекторіїв забезпечувала проведення не менше 2-3 лекції на місяць у кожному населеному пункті області. У 1947 р., порівняно з попереднім 1946 р., значно збільшилась кількість лекцій, прочитаних лекторами Миколаївського обласного лекційного бюро і районних лекторських груп. Так, наприклад, у 1945 р. прочитано 2163 лекції, в 1946 р. - 9837, а в 1947 р.- 15236 лекцій докладів і бесід ${ }^{41}$.

Значною подією у культурному житті визволених районів України стало відкриття професіональних театрів. На початку 1945 р. засвітилися рампи чотирьох миколаївських театрів: Російської драми імені В.П. Чкалова, Юного глядача, Лялькового, Українського пересувного колгоспного театру. Вони проводили велику роботу з культурного обслуговування сільського населення. Театри відігравали велику роль в ідейно-політичному й естетичному вихованні громадян, у пропаганді ідей соціалізму. В їх репертуарі були п'єси радянських драматургів: «Кремлівські куранти» М. Погодіна, «Платон Кречет» О.Корнійчука, «Російські люди» К. Симонова, «Розкинулось море Широке» В. Вишневського, «Надзвичайний посол» братів Тур і Л. Шейиіна та багато інших ${ }^{42}$.

У 1952 р. театр імені Чкалова систематично виїжджав у райони області для обслуговування глядачів у колгоспах спектаклями, але через відсутність палива план обслуговування районів області часто зривався 43 . Недоліком їх роботи можна назвати те, що вони виїжджали не в село, для виконання поставлених завдань по обслуговуванню сільських мас, а у районні центри в гонитві за великою виручкою 44.

Успіх роботи культурно-освітніх установ залежав від правильного добору, розстановки та виховання кадрів. Склад завідуючих клубами у цілому складався з молоді, яка не мала ні спеціальної освіти, ні достатнього досвіду роботи ${ }^{45}$. Підбір кадрів проводився, головним чином, за рахунок демобілізованих з Червоної Армії46.

У 1946 р. в Миколаївській області з 22 завідуючих клубів з вищою освітою був 1, 3 незакінченою вищою освітою - 1, середньою - 9, неповною середньою - 147. Серед працівників культосвітніх закладів у повоєнний період спостерігалася велика плинність кадрів, що була викликана низькою заробітною платою48, а також невиплатою заробітної плати по декілька місяців ${ }^{49}$, погані побутові умови ${ }^{50}$, невідповідальне ставлення керівників до проблем клубної роботи 51 , наявність фактів свавілля з боку місцевих радянських і партійних органів - основні причини звільнення з роботи культпросвітпрацівників.

\footnotetext{
40 ДАМО Ф. П-7. Оп. 4. Спр. 334. Арк. 49.

41 Ibid. Спр. 210. Арк. 5.

42 Носіков Ю.В. Вказ. пр. С. 70.

43 ДАМО. Ф. Р-992. Оп. 6. Спр. 1393. Арк. 57.

${ }^{44}$ Носіков Ю.В. Вказ. пр. С. 70.

45 ДАМО. Ф. П-7. Оп. 4. Спр. 210. Арк. 20-21.

46 ДАХО. Ф. Р-1989. Оп. 1. Спр. 27. Арк. 8.

47 ДАМО. Ф. П-7. Оп. 4. Спр. 210. Арк. 33.

48 ДАХО. Ф. Р-1989. Оп. 1. Спр. 55. Арк. 8.

49 ДАМО. Ф. П-7. Оп. 4. Спр. 334. Арк. 76.

50 Ibid. Спр. 189. Арк. 64.

51 Терещенко Т.В. Вказ. пр. С. 356.
} 
Більшість сільських рад і деякі керівники первинних партійних і, навіть, комсомольських організацій, абсолютно незважаючи на вимоги номенклатури, знімали та призначали керівників сільських клубів без відома не лише райвідділів культурнопросвітницької роботи, але й без відома виконкомів районних рад. Так, у 1950 р. на Миколаївщині змінили 47 робітників по області, у тому числі - 16 завідувачів клубів 52. У 1951 р. у ряді районів області не припинилася плинність серед керівників сільських клубів. Відмічено низку випадків, коли в окремих селах посади завідувачів сільськими клубами розглядалися, як допоміжне джерело доходів і в ролі завідувачів клубами за сумісництвом виявлялися голови сільрад або інші керівні працівники 53.

Більшість сільських культурно-освітніх установ Миколаївської області було знищено або розорено під час окупації. Вони знаходилася у скрутному, занедбаному стані. Кількість клубів зменшилася більш як удвічі. Клуби стали основним осередком суспільно-культурного життя та спілкування селян, що істотно впливало на формування суспільної думки, настроїв і загальної культури сільського населення. Культурно просвітницькі установи стали центром пропаганди ідей партії. Характерною рисою діяльності клубних установ стала надмірна політизація й ідеологізація. Недоліки роботи клубних установ були пов'язані з тим, що вони розглядалися владою не як осередки духовності, а як інструмент для вирішення економічних, політичних, соціальних та ідеологічних завдань. Основними напрямами роботи сільських клубів було: роз'яснення поточних політичних подій, політична й науковопросвітницька пропаганда, організація культурного відпочинку, діяльність художньої самодіяльності селян, масова політична та культурно-освітня робота під час польових робіт. Мета культурно-просвітницьких установ - це вплив на свідомість селян шляхом ідеологічного тиску для виконання політичних і сільськогосподарських завдань. Все ж була проведена значна робота по відновленню культурноосвітніх установ і створенню передумов росту культурного рівня сільського населення.

У повоєнний період мережа культурно-просвітніх установ на Миколаївщині відновлювалася, переважно, за рахунок і силами самих селян. Створювалися гуртки художньої самодіяльності, знову ж таки за ініціативою самих же селян. До районних і сільських клубів приїжджали кінопересувки, ставили п'єси новостворені театри. I звичайно ж основна робота культурно-просвітніх установ полягала у проведені лекторіїв. Діяльність всіх культурно-просвітницьких установ у досліджуваний період жорстко регламентувалася вищим партійним керівництвом. Суворо перевірявся репертуар і виконавці, робота культпрацівників стримувалася партійною верхівкою, а їі розвиток призупинявся.

\section{REFERENCES}

Michuda, V. (2003). Kulturne budivnytstvo na seli v pershi povoienni roky (1945-1950 rr.) [Cultural construction in the village in the first postwar years (1945-1950)]. Ukraina XX stolittia: kultura, ideolohiia, polityka, (7), 403-408 [in Ukrainian].

Nosikov, Yu.V. (1978). Vidbudova zakladiv kultury, osvity ta okhorony zdorovia v 1943-1945 rr. [Reconstruction of institutions of culture, education and health in 1943-1945]. Ukrainskyi istorychnyi zhurnal, 5, 69-73 [in Ukrainian].

Romaniuk, I.M. (2005). Ukrainske selo v 50-ti - pershii polovyni 60-kh rr. XX st. [Ukrainian village in the 50 's - the first half of the 1960's] Vinnitsa: Knyha-Veha [in Ukrainian].

\footnotetext{
52 ДАМО. Ф. П-7. Оп. 8. Спр. 26. Арк. 71.

53 ДАМО. Ф. Р-992. Оп.6. Спр.450. Арк. 4.
} 
Rumiantsev, S. (1999). Samodeiatelnoe khudozhestvennoe tvorchestvo v SSSR: ocherki istorii 19501990 gg. [Amateur art creativity in the USSR: essays on the history of 1950-1990]. Moscow: ROSSPEN [in Russian].

Rybak, I.V. (2000). Sotsialno-pobutova infrastruktura ukrainskoho sela 1921-1991 rr. [Social-household infrastructure of the Ukrainian village of 1921-1991]. Kamenets-Podolsky: Abetka [in Ukrainian].

Tereschenko, T.V. (2004). Vidbudova silskykh kulturno-osvitnikh ustanov u 1943-1950 rr. (na materialakh Tsentralnoi Ukrainy) [Rebuilding rural cultural and educational institutions in 19431950 (on materials of Central Ukraine)]. Istoriia Ukrainy. Malovidomi imena, podii, fakty, (26), 353366 [in Ukrainian].

Shamrai, O.H. (2008). Khudozhnia samodiialnist ta inshi formy dozvillia u povoiennomu ukrainskomu seli [Artistic activity and other forms of leisure in the post-war Ukrainian village]. Visnyk Cherkaskoho universytetu. Seriia «Istorychni nauky», 133-134, 161-166 [in Ukrainian].

\section{Hanna Marynchenko}

(Mykolaiv National University named after V. Sukhomlinsky, Mykolaiv, Ukraine)

ORCID: https://orcid.org/0000-0003-3208-0546

\section{Vira Revenko}

(Mykolaiv National University named after V. Sukhomlinsky, Mykolaiv, Ukraine)

ORCID: https://orcid.org/0000-0002-1043-6890

\section{Restoration and Activity of Clubs in Mykolaiv Region in the Post-War Period} (1945-1955)

The paper discloses the features of restoration and activity of cultural and educational institutions in the countryside of Mykolaiv Region, their cultural, educational, and political and mass work with the peasantry in the post-war period.

In the post-war period, the network of cultural and educational institutions in Mykolaiv Region was restoring mainly at the expense and by the peasants themselves. In some villages and collective farms, there were facts of use of cultural and educational institutions not for the intended purpose: clubs were filled with grain, rebuilt for dryers, stables, poultry yards, dormitories, etc.

The appearance of the clubs was also quite unattractive. They were abandoned, dirty, roofless, with damaged corners, the walls and ceilings were cracked, they were not lighted because windows were laid with stone. There was no greenery around the clubs, and it was dirty under the windows. Most clubs needed complete inside overhaul, there were no floors, the stoves, ceilings, and walls collapsed.

The success of cultural and educational institutions depended on the correct selection, positions, and education of staff. The heads of clubs were mostly young people who had neither special education nor sufficient work experience. Amateur arts circles were created, again on the initiative of the peasants themselves. District and village clubs were visited by moving cinemas with portable film projectors and newly created theatres with their plays. And of course, the main work of cultural and educational institutions included lectures.

The activities of all cultural and educational institutions were rigorously regulated by the senior Party leadership. The repertoire and performers were strictly checked. It was the main reason why the work of the organizers of cultural activities was suppressing and its development was suspended.

Keywords: cultural center, cultural and educational work, amateur arts, leisure, peasantry, Mykolaiv region 